\title{
ANALISIS KUALITAS AIR EKOSISTEM MANGROVE DI ESTUARI PERANCAK, BALI
}

\author{
Susiana \\ Staf Pengajar FIKP UMRAH-Kep. Riau, e-mail: susiana_l21107001@yahoo.com
}

\begin{abstract}
ABSTRAK
Penelitian ini bertujuan menganalisis kualitas air mangrove alami dan rehabilitasi, meliputi DO, salinitas, suhu, $p H$, nitrat, dan ammonia serta fraksi sedimen. Penelitian dilaksanakan pada Januari hingga Maret 2011 bertempat di estuari Perancak, Bali. Data dianalisis di Balai Riset Observasi Kelautan (BROK) Jembrana, Bali. Pengukuran kualitas air dan fraksi sedimen dibagi kedalam 4 (empat) sublokasi pada masing-masing lokasi. Masing-masing sub-lokasi mewakili kondisi dan karakter lingkunga, yakni dekat muara, pertengahan dan jauh dari muara. Pengukuran dilakukan insitu dan laboratorium. Kualitas air dan fraksi sedimen masing-masing zona di analisis secara deskriptif. Hasil penelitian menunjukkan bahwa kondisi kualitas perairan pada daerah mangrove alami memiliki kisaran yang luas (DO antara 1,75-3,54 mg/l, suhu antara 29,08-30,50 ${ }^{\circ} \mathrm{C}$, salinitas antara 20,16$38,27 \%$, pH antara 7,99-8,13, $\mathrm{NO}_{3}$ antara $0,1391-0,4037 \mathrm{mg} / \mathrm{l}$ serta $\mathrm{NH}_{4}$ antara 0,0539 $0,1423 \mathrm{mg} / \mathrm{l}$ ) dibanding pada daerah mangrove rehabilitasi dengan kisaran kualitas air sempit (DO antara 1,85-2,20 mg/l, suhu antara $29,01-29,41{ }^{\circ} \mathrm{C}$, salinitas antara 17,41 $22,87 \%$, $p H$ antara $7,86-7,97, \mathrm{NO}_{3}$ antara $0,1590-0,2693 \mathrm{mg} / \mathrm{l}$ dan $\mathrm{NH}_{4}$ antara $0,0857-0,0947$ $\mathrm{mg} / \mathrm{l}$ ). Fraksi sedimen pada daerah mangrove rehabilitasi komponen pasir dan liat dalam porsi yang relatif kecil dibanding dengan daerah mangrove alami. Selain itu, komposisi fraksi sedimen pada mangrove alami cenderung lebih stabil dibanding mangrove rehabilitasi cenderung fluktuatif. Perbedaan kualitas air dan fraksi sedimen diduga kuat memperngaruhi struktur dan komposisi mangrove, gastropoda dan bivalvia yang ada di lokasi tersebut. Selain itu, perbedaan tersebut terkait erat dengan kestabilan ekosistem dan keberadaan muara sungai yang diduga turut berpengaruh terhadap kondisi tersebut.
\end{abstract}

Kata Kunci: Kualitas Perairan, Sedimen dan Mangrove

\section{PENDAHULUAN}

1.1. Latar Belakang

Secara harfiah, mangrove memiliki arti ganda, yakni sebagai komunitas sekaligus sebagai spesies. Komunitas mangrove, umumnya disebut "mangal" dan "mangrove" merupakan sebutan untuk individu tumbuhan (Sidik, 2005). Hutan mangrove merupakan komunitas vegetasi tumbuhan pantai tropis di kawasan lembab dan berlumpur, dipengaruhi pasang surut air laut (Bengen, 2000). Mangrove berasal dari kata
"Mangue" Afrika Barat, Senegal, Gambia, dan Guinea. Abad ke-XV Portugis mengadopsi dan menyebarkannya ke seluruh dunia. Orang-orang Spanyol mengadopsi kata "Mangle" dan "Manglar". Mangrove dalam istilah Inggris merupakan derivasi dari istilah Portugal atau Spanyol yang berarti hutan yang terdiri dari Mangue (Macintosh, et al., 2002). Mangrove merujuk pada komunitas, bakau merujuk pada jenis. Bakau menunjuk mangrove jenis Rhyzopora (Hidayatullah, et al., 2014). Mangrove 
juga didefenisikan sebagai pohon dan semak dari genera Rhizophora, Brugiera, Sonneratia dan Avicennia atau komunintas yang didominasi oleh genera sebagai komponen biotik (IUCN, 2007).

Sebagai komunitas, mangrove merupakan vegetasi pantai tropis dan sub-tropis, didominasi beberapa jenis Avicennia, Sonneratia, Rhizophora, Bruguiera, Ceriops, Lumnitzera, Exoecaria, Xylocarpus, Aegiceras, Scyphyphora dan Nypa yang tumbuh dan berkembang pada daerah pasang surut pantai berlumpur (Bengen, 2004). Vegetasi mangrove secara khas memperlihatkan adanya pola zonasi, hal tersebut terkait erat dengan tipe tanah (lumpur, pasir atau gambut), terbuka terhadap hempasan gelombang, salinitas serta pengaruh pasang surut (Noor, et al., 1999). Mangrove berada di daerah muara sungai yang merupakan tujuan akhir dari partikel-partikel organik dan endapan lumpur yang terbawa dari hulu oleh erosi. Dengan demikian, daerah mangrove merupakan daerah subur, baik daratan maupun perairannya, oleh karena selalu terjadi transportasi nutrien akibat pasang surut (Gunarto, 2004). Sehingga mangrove tumbuh baik sepanjang pantai tropis terlindung seperti delta pada sungai besar (Macintosh, et al., 2002).

Mangrove di Bali tersebar pada beberapa lokasi dengan luas sekitar $3.067,71$ ha, terdiri dari 2.177,5 ha terdapat dalam kawasan hutan dan 890,4 ha di luar kawasan hutan. Mangrove terluas tersebar pada tiga lokasi. Pertama terletak di Tanjung Benoa dan Pulau Serangan dikenal sebagai Tahura atau Taman Hutan Raya Ngurah Rai seluas 1.373,5 ha. Kedua terletak di Nusa Lembongan seluas 202 ha. Ketiga terletak di Taman Nasional Bali Barat seluas 602 ha. Mangrove di kawasan Estuari Perancak dengan luas 177,09 ha merupakan sisa luas hutan setelah di konversi menjadi areal pertambakan sekitar tahun 1980 (BROK, 2009). Selanjutnya dikatakan, lebih dari 390 ha merupakan lahan tambak, baik yang masih produktif maupun yang tidak produktif lagi, serta 178,6 ha merupakan mangrove.

Suburnya mangrove di Indonesia karena ditunjang oleh iklim tropis, curah hujan tinggi, serta lumpur atau sedimen pantai yang cocok untuk pertumbuhan mangrove (Bengen, 2000). Komunitas mangrove terdiri dari spesies yang memiliki adaptasi spesifik, menjadikannya bertahan hidup dalam tekanan-tekanan alam seperti difensiasi salinitas, pasang surut, arus dan gelombang. Dengan demikian, zona vegetasi mangrove terkait erat dengan pasang surut (Sidik, 2005).

Ekosistem mangrove merupakan salah satu ekosistem dengan produktifitas tinggi, karena adanya dekomposisi serasah. Mangrove memberikan kontribusi besar terhadap detritus organik yang sangat penting sebagai sumber energi bagi biota yang hidup di perairan sekitarnya. Gastropoda dan bivalvia pada ekosistem mangrove berperan penting dalam proses dekomposisi serasah dan mineralisasi materi organik terutama yang bersifat herbivor dan detrivor. Dalam rantai makanan pada ekosistem hutan mangrove, gastropoda dan bivalvia berkedudukan sebagai dekomposer (Noor, et al., 1999). Dengan demikian, pengetahuan tentang parameter fisika dan kimia perairan mangrove menjadi penting. Untuk menjawab hal itu, perlu dilakukan penelitian analisis parameter fisika dan kimia perairan ekosistem hutan mangrove yang bertempat di estuari Perancak, Bali.

\subsection{Tujuan dan Kegunaan}

Penelitian dilaksanakan dengan tujuan untuk mengetahui perbandingan kualitas perairan mangrove alami dan rehabiltasi, untuk mengetahui fraksi sedimen mangrove alami dan rehabilitasi dan untuk mengetahui hubungan kualitas perairan dengan fraksi sedimen terhadap pertumbuhan spesies mangrove dan gastropoda. Penelitian diharapkan memberi informasi akurat dalam rangka pengembangan kawasan mangrove sebagai kawasan konservasi di estuari Perancak, Bali

\section{METODE PENELITIAN}

\subsection{Waktu dan Tempat}

Penelitian dilaksanakan pada bulan Januari sampai dengan bulan Maret 2011 bertempat estuari Perancak, Bali. Analisis data dilakukan pada Balai Riset dan Observasi 
Kelautan (BROK), Kabupaten Jembrana, Provinsi Bali. Peta lokasi penelitian ditunjukan pada Gambar 1.

\subsection{Alat dan Bahan}

Alat dan bahan yang digunakan dalam penelitian dibedakan atas 3 (tiga) parameter yang diamati, yakni parameter sedimen menggunakan Eickman Grap dan saringan $500 \mathrm{~nm}$ untuk mengambil sedimen, serta kantong plastik sebagai bahan penyimpanan sampel. Parameter fisika menggunakan termometer untuk mengukur suhu perairan. Parameter kimia, terdiri atas salinitas menggunakan refraktometer, $\mathrm{pH}$ menggunakan $\mathrm{pH}$ meter digital, DO menggunakan DO meter, dan Nitrat dan Ammonia menggunakan spektrofotometer.

\subsection{Metode Kerja}

\subsubsection{Penentuan Zona Pengamatan}

Zona pengamatan ditetapkan secara purposive pada 2 (dua) lokasi yang berbeda. Untuk zona 1 merupakan kawasan mangrove alami dan zona 2 merupakan kawasan mangrove rehabilitasi. Masing-masing zona terdiri atas 4 (empat) stasiun, setiap stasiun terdiri atas 3 (tiga) sub-stasiun pengamatan, masing- masing berukuran $10 \mathrm{~m}^{2}$ yang dibedakan menurut karakter lokasi dekat muara, pertengahan dan jauh dari laut dan atau sungai.

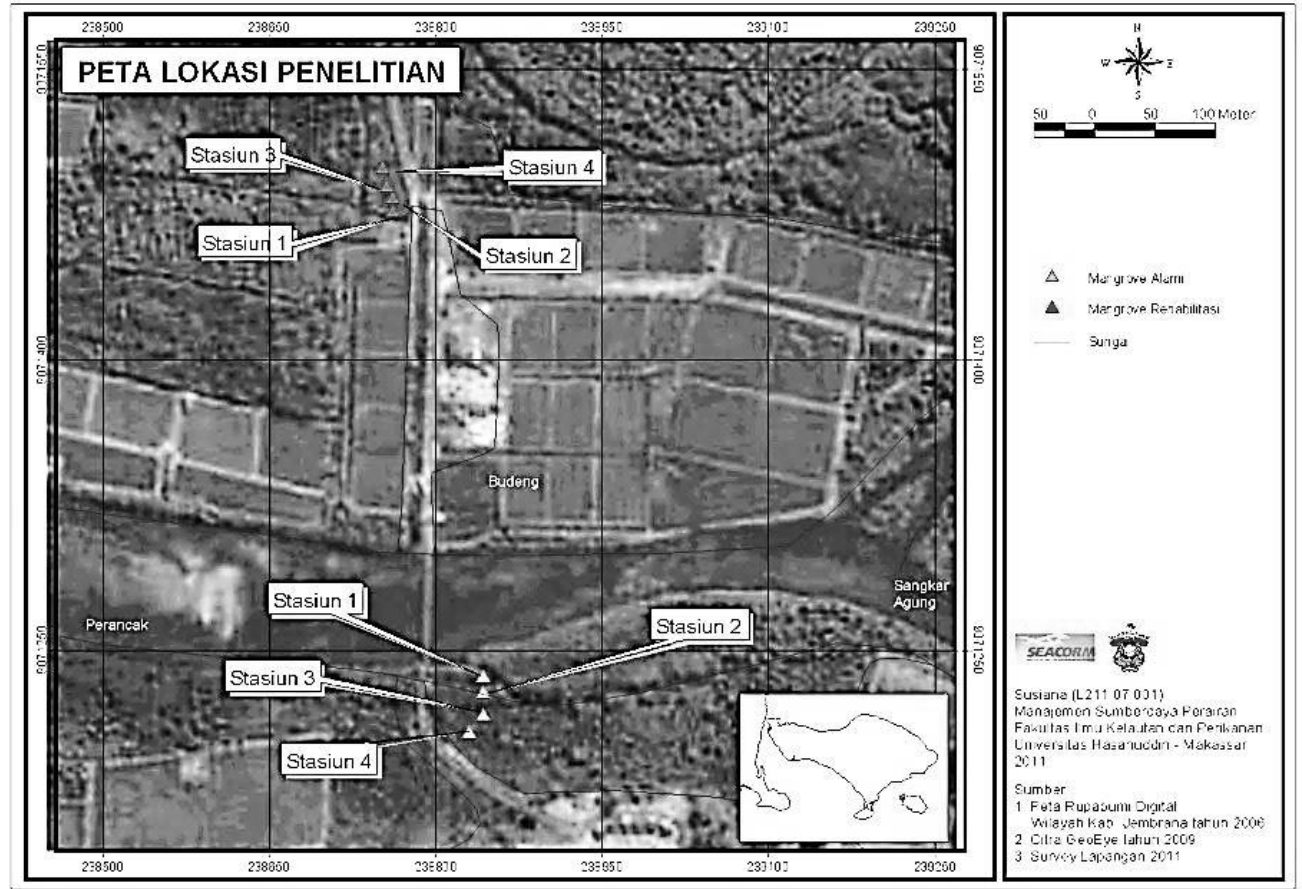

Gambar 1. Lokasi Penelitian pada Balai Riset dan Observasi Kelautan, Kabupaten Jembrana, Bali,

\subsubsection{Prosedur Pengambilan Data}

Pengambilan data, dilakukan pada setiap stasiun pengamatan yang telah ditentukan. Sementara pada masing-masing sub-stasiun ditetapkan areal pengamatan sebesar $10 \mathrm{~m}^{2}$ (Gambar 2).

Sementara itu pada setiap stasiun tersebut ditentukan sub-stasiun pengamatan menggunakan plot (transek) area ukuran $1 \mathrm{~m}^{2}$. Ploting area tersebut dijadikan tempat untuk pengambilan data meliputi pengukuran insitu kualitas air meliputi DO, salinitas, suhu dan $\mathrm{pH}$ dan pengambilan sampel tanah dan air untuk pengamatan tekstur tanah dan pengukuran nitrat $\left(\mathrm{NO}_{3}\right)$ dan ammonia $\left(\mathrm{NH}_{4}\right)$ di laboratorium.

\subsubsection{Data Kualitas Air}

Pengambilan sampel air laut dilakukan berdasarkan periode pasang-surut air laut agar diketahui fluktuasi kualitas air berdasarkan 
periode pasang-surut air. Pembedaan pasangsurut air laut dilakukan dengan bantuan prediksi pasang-surut air laut secara insitu di lokasi penelitian. Data parameter kualitas air meliputi suhu, $\mathrm{pH}$, salinitas, $\mathrm{DO}$, nitrat dan ammonia.

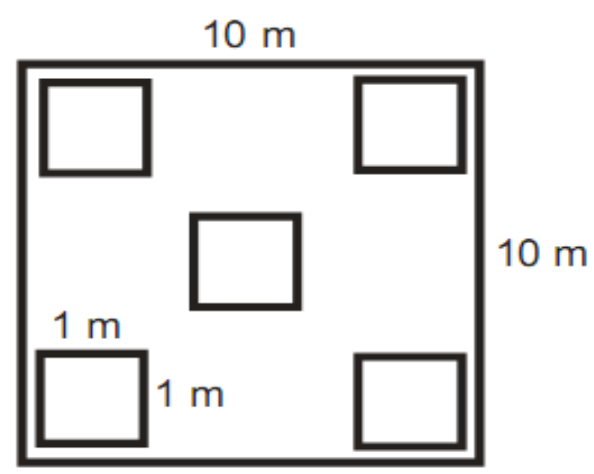

Gambar 2. Plot atau transek kuadrat yang digunakan dalam penelitian

\subsubsection{Data Tekstur Tanah}

Data tekstur tanah berupa sedimen hanya diambil pada waktu periode surut air, dengan bantuan alat Eickman Grap. Sampel tanah yang diambil pada setiap stasiun diuji di Laboratorium Tanah, BROK Jembrana, Bali untuk melihat komposisi fraksi pasir, debu dan liat.

\section{HASIL DAN PEMBAHASAN}

\subsection{Kualitas Perairan Mangrove}

Hasil analisis data parameter kualitas air mengekspresikan kondisi kualitas perairan magrove di estuaria Perancak, Bali. Hasil analisis data kualitas air berdasarkan kondisi hutan mangrove alami dan rehabilitasi disajikan pada Tabel 1.

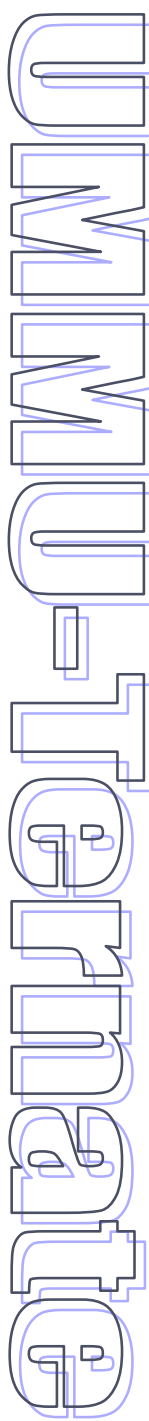

Tabel 1. Kondisi Parameter Kualitas Air Berdasarkan Periode Pasang-Surut Air Laut Pada Mangrove Alami Dan Mangrove Rehabilitas

\begin{tabular}{ccccccc}
\hline \multirow{2}{*}{$\begin{array}{c}\text { Kondisi } \\
\text { Mangrove }\end{array}$} & \multicolumn{6}{c}{ Parameter Kualitas Air } \\
\cline { 2 - 7 } & $\mathbf{D O}(\mathrm{mg} / \mathrm{l})$ & $\begin{array}{c}\text { Suhu } \\
\left({ }^{\circ} \mathrm{C}\right)\end{array}$ & $\begin{array}{c}\text { Salinitas } \\
(\%)\end{array}$ & $\mathrm{pH}$ & $\begin{array}{c}\text { Nitrat }\left(\mathrm{NO}_{3}\right) \\
(\mathbf{m g} / \mathbf{l})\end{array}$ & $\begin{array}{c}\text { Ammonia } \\
\left(\mathrm{NH}_{4}\right)(\mathbf{m g} / \mathrm{l})\end{array}$ \\
\hline 1 & 3 & 4 & 5 & 6 & 7 & 8 \\
\hline Alami & $1,75-3,54$ & $29,08-30,50$ & $\begin{array}{c}20,16- \\
38,27\end{array}$ & $7,99-8,13$ & $0,1391-0,4037$ & $0,0539-0,1423$ \\
Rehabilitasi & $1,85-2,20$ & $29,01-29,41$ & $17,41-22,87$ & $7,86-7,97$ & $0,1590-0,2693$ & $0,0857-0,0947$ \\
\hline
\end{tabular}

Berdasarkan Tabel 1, diketahui bahwa parameter kualitas air di daerah mangrove alami relatif berfluktuasi cukup tinggi. Hal ini terlihat dari range fluktuasi yang cukup lebar yakni konsentrasi DO berkisar antara 1,75-3,54 mg/1 pada saat surut dan pasang. Konsentrasi nitrat berkisar antara 0,1391-0,4037 mg/l. Kadar pH relatif konstan, yakni berkisar antara 7,99-8,13. Konsentrasi nitrat berkisar antara 0,0539-0,1423 $\mathrm{mg} / \mathrm{l}$, dengan kandungan salinitas dan suhu masing-masing berkisar antara $20,16-38,27 \%$ dan $29,08-30,5{ }^{\circ} \mathrm{C}$. Sementara kualitas air pada daerah mangrove rehabilitasi ditemukan dengan nilai kisaran sempit antar setiap parameter yang diukur. Konsentrasi DO berkisar antara sebesar 1,85-2,20 mg/l, kadar ammonia berkisar antara sebesar 0,0857-0,0947 mg/l. Kadar $\mathrm{pH}$ berkisar anatar sebesar 7,86-7,97. Konsentrasi nitrat berkisar antara sebesar 0,159-0,2693 $\mathrm{mg} / \mathrm{l}$. Salinitas dan suhu masing-masing berkisar antara sebesar 17,41-22,87 \% dan 29,01-29,41 ${ }^{\circ} \mathrm{C}$.

Kualitas air relatif berpengaruh terhadap kerapatan jenis mangrove (Tis'in, 2008). Berdasarkan pernyatan tersebut dan hasil pengukuran kualitas air dapat dikatakan bahwa pada daerah mangrove alami di setiap stasiun pengamatan memungkinkan adanya fluktuasi unsur hara yang dibutuhkan mangrove. Hal ini di duga karena pada daerah mangrove alami terletak dekat muara sungai, dengan demikian fluktuasi kualitas air terjadi dengan baik. Hal ini terjadi melalui aliran air sungai pada saat pasang surut air. Kondisi perairan tersebut memungkinkan mangrove memiliki tingkat kerapatan jenis tinggi. Namun kondisi tersebut tidak terjadi pada daerah mangrove rehabilitasi, 
oleh karena kerapatan mangrove yang tinggi sengaja dilakukan melalui penanaman. Namun demikian, parameter kualitas air relatif berpengaruh terhadap kelangsungan hidup mangrove (Susiana, 2011).

Pada daerah mangrove alami cenderung ditemukan gastropoda yang seragam, tingkat keanekaragaman sedang. Gastropoda umumnya merupakan hewan sessil dengan pergerakan lambat. Dengan demikian kondisi hidupnya sangat dipengaruhi oleh faktor fisika dan kimiawi tanah dan air, diantaranya $\mathrm{pH}$, nitrat, maupun ammonia. Dengan konsentrasi $\mathrm{pH}$ yang berkisar antara sebesar 7,99-8,13 dan nitrat antara sebesar 0,0539-0,1423 mg/1 ditemukan gastropoda relatif seragam dengan tingkat keanekaragaman relatif sedang. Merujuk baku mutu lingkungan, toleransi organisme terhadap $\mathrm{pH}$ air berkisar antara 6,5-8,5 (MNLH, 2004), dengan demikian pH tersebut masih dalam ambang batas toleransi.

Perbedaan parameter kualitas air antara daerah mangrove alami dan mangrove rehabilitasi diduga karena faktor lokasi. Mangrove alami berada dekat dengan muara sungai, sementara mangrove rehabilitasi berada relatif jauh dari muara sungai. Keberadaan muara sungai sekitar mangorve berpengaruh terhadap kepadatan gastropoda dan bivalvia yang berasosiasi (Susiana, 2011). Dengan demikian, perombakan bahan organik dalam hal ini nitrat oleh mikroorganisme yang menghasilkan senyawa asam organik berbeda antara kedua lokasi. Perombakan bahan organik tersebut berpotensi menurunkan pH (Tis'in, 2008). Hal ini terlihat dari $\mathrm{pH}$ pada mangrove rehabilitasi yang relatif konstan atau tidak memiliki kisaran yang luas, sementara pada mangrove alami memiliki kisaran yang relatif lebar. Kisaran $\mathrm{pH}$ terjadi karena adanya pengaruh kapasitas penyangga dari garam-garam karbonat dan bikarbonat yang tinggi (Bengen, 2000). Hal yang sama ditemukan di Tanakeke, Sulawesi Selatan dimana $\mathrm{pH}$ berkisar antara sebesar 7,2-7,5 dengan kandungan nitrat berkisar antara $0,45-1,17 \mathrm{mg} / 1$ (Tis'in, 2008). Dekomposisi bahan organik mikroorganisme terjadi pada $\mathrm{pH}$ normal sehingga konsentrasi bahan organik di daerah Perancak cenderung lebih rendah dibanding pada daerah Kepulauan Tanakeke, dimana dekomposisi bahan organik terjadi pada $\mathrm{pH}$ basa (Tis'in, 2008). Nilai pH mempengaruhi proses biokimia perairan seperti proses nitrifikasi, dengan hasil akhir pada kondisi $\mathrm{pH}$ rendah (Bengen, 2000).

\subsection{Fraksinasi Sedimen Mangrove}

Fraksinasi sedimen dilakukan dengan tujuan untuk mengetahui pola kerapatan dan kejarangan suatu ekosistem, dalam hal ini mangrove. Berdasarkan hasil pengamatan fraksi sedimen mangrove pada ke-empat stasiun pengamatan, baik pada mangrove alami maupun mangrove rehabilitasi ditemukan substrat lempung berdebu. Hal ini menunjukkan bahwa sebagian besar mangrove alami maupun rehabilitasi, tumbuh pada kondisi substrat lempung berdebu. Hal ini ditunjukkan pada Tabel 2.

Tabel 2. Fraksi sedimen Mangrove bulan Januari.

\begin{tabular}{ccccc}
\hline Kondisi Mangrove & $\begin{array}{c}\text { Sub-stasiun } \\
\text { Pengamatan }\end{array}$ & $\begin{array}{c}\text { Fraksi } \\
\text { Debu (\%) }\end{array}$ & $\begin{array}{c}\text { Fraksi } \\
\text { Liat (\%) }\end{array}$ & $\begin{array}{c}\text { Fraksi } \\
\text { Pasir (\%) }\end{array}$ \\
\hline \multirow{3}{*}{ Alami } & I & 52.2 & 27.15 & 20.65 \\
& II & 50.01 & 35.56 & 14.43 \\
III & 53.07 & 35.77 & 11.17 \\
Rehabilitasi & IV & 53.25 & 41.58 & 5.17 \\
\hline & I & 59.75 & 28.83 & 11.43 \\
& II & 64.06 & 11.02 & 28.83 \\
& III & 54.63 & 34.35 & 11.02 \\
IV & 46.68 & 50.35 & 2.97 \\
\hline
\end{tabular}


Komposisi fraksi liat sedimen mangrove alami dan rehabilitasi dengan persentase berkisar antara 27,15-50,35\%. Persentase tertinggi ditemukan pada sub-stasiun IV kondisi mangrove rehabilitasi didominasi jenis mangrove Rhizophora stylosa dan Avicennia alba, sementara presentase kandungan pasir sedimen mangrove alami dan rehabilitasi berkisar antara $5,17-28,83 \%$ didominasi mangrove jenis Rhizophora sp. dan Avicennia alba. Komposisi tertinggi fraksi debu sedimen mangrove rehabilitasi ditemukan pada bulan Februari di sub-stasiun III (Gambar 4) dengan persentase sebesar $72,63 \%$, didominasi mangrove jenis Rhizophora stylosa dan Rhizophora mucronata. Sementara komposisi terendah fraksi debu sedimen mangrove alami ditemukan pada bulan Januari di sub-stasiun III dengan persentase sebesar $42,43 \%$ didominasi mangrove jenis Rhizophora mucronata.

Tabel 3. Fraksi sedimen mangrove bulan Februari.

\begin{tabular}{ccccc}
\hline Kondisi Mangrove & $\begin{array}{c}\text { Sub-stasiun } \\
\text { Pengamatan }\end{array}$ & $\begin{array}{c}\text { Fraksi } \\
\text { Debu (\%) }\end{array}$ & $\begin{array}{c}\text { Fraksi } \\
\text { Liat (\%) }\end{array}$ & $\begin{array}{c}\text { Fraksi } \\
\text { Pasir (\%) }\end{array}$ \\
\hline Alami & I & 50.14 & 38.11 & 11.75 \\
& II & 51.3 & 41.53 & 7.18 \\
& III & 42.43 & 43.03 & 14.55 \\
IV & 60.03 & 30.3 & 9.67 \\
\hline Rehabilitasi & I & 71.13 & 13.32 & 15.55 \\
& II & 72.16 & 15.07 & 12.77 \\
& III & 72.63 & 14.96 & 12.41 \\
IV & 71.24 & 11.83 & 16.93 \\
\hline
\end{tabular}

Persentase fraksi liat pada sedimen mangrove rehabilitasi dan alami berkisar antara $11,83-43,03 \%$, persentase fraksi tertinggi ditemukan pada sub-stasiun II mangrove alami. Fraksi sedimen dengan komposisi yang relatif stabil didominasi mangrove jenis Rhizophora stylosa dan Rhizophora mucronata (Susiana, 2011). Selanjutnya dikatakan bahwa persentase fraksi pasir pada mangrove alami dan rehabilitasi berkisar antara 7,18-16,93\% tumbuh mangrove jenis Rhizophora sp. dan Avicennia alba. Menurut Reid (1986), zonasi bakau dipengaruhi oleh berbagai faktor lingkungan antara lain pasang surut, curah hujan dan sedimentasi substrat (Pulungsari, 2004).

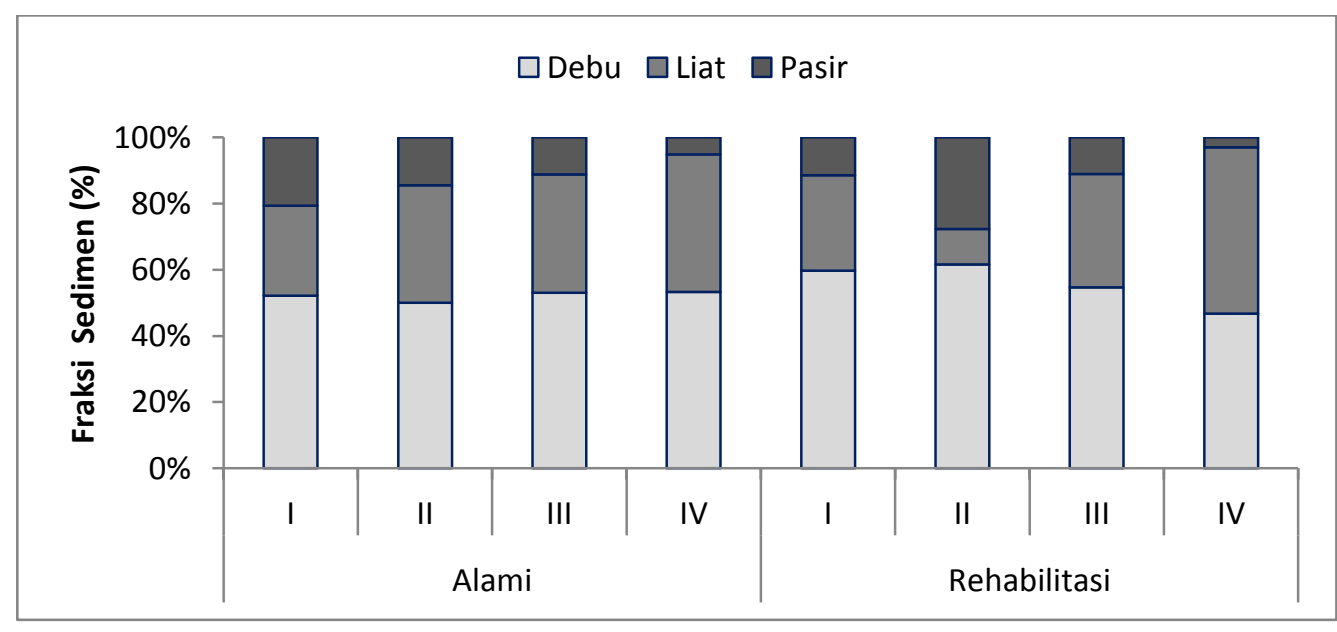

Gambar 3. Hasil analisis fraksi sedimen mangrove bulan Januari. 


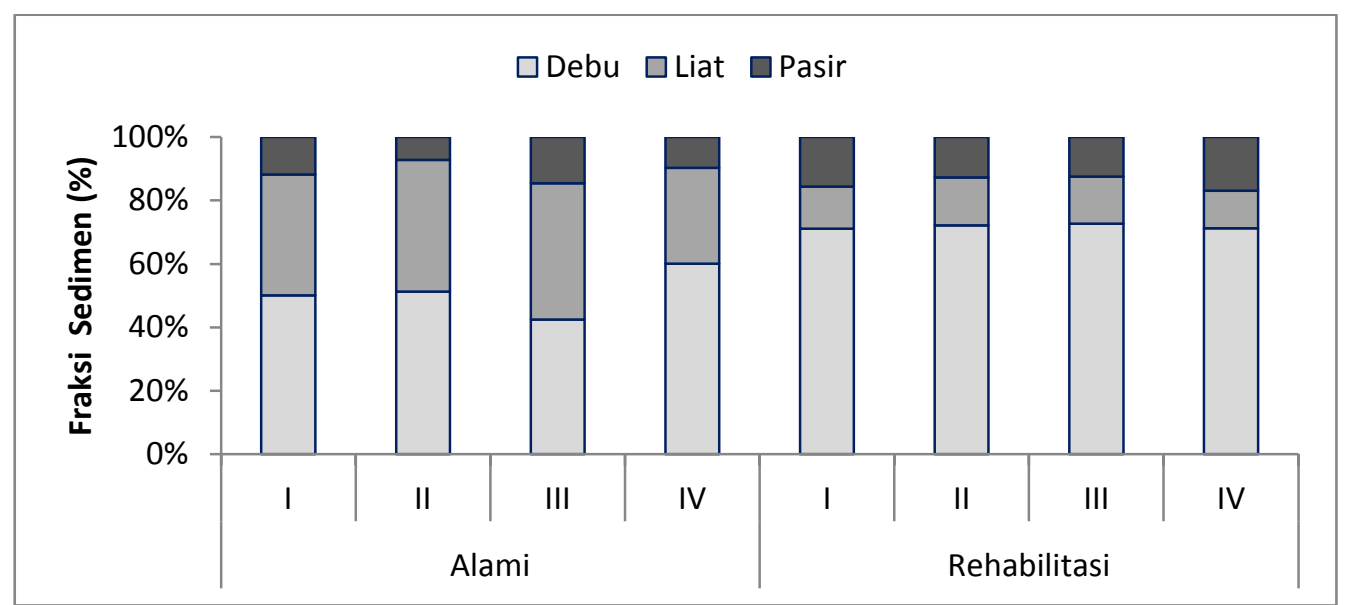

Gambar 4. Hasil analisis fraksi sedimen mangrove bulan Februari.

Secara umum, fraksi sedimen pada daerah mangrove alami lebih didominasi oleh debu dan liat dengan komposisi yang cenderung konstan. Hal ini diduga turut mempengaruhi kualitas air di areal pengamatan khususnya nitrat, ammonia dan $\mathrm{pH}$. Sementara pada daerah mangrove rehabilitasi, komponen pasir dan liat dalam porsi yang relatif kecil dibanding dengan daerah mangrove alami dengan komposisi relatif fluktuatif (Gambar 3 dan 4). Komposisi sedimen mempengaruhi jenis dan jumlah tumbuhan mangrove yang hidup. Oleh karena tumbuhan mangrove memiliki bentuk perakaran berbeda pada setiap jenis substrat, hal ini semakin menegaskan bahwa bentuk perakaran tersebut merupakan salah satu bentuk adaptasi terhadap jenis substrat. Terkait dengan organisme asosiasi mangrove, komposisi fraksi sedimen memiliki peranan yang sangatlah penting mengingat beberapa jenis bivalvia dan gastropoda sebagai filter feeder (Natan, 2008), maupun sebagai pengambil oksigen (Lebata, 2001), sulfida (Lebata, 2000) dan nutrien oleh $A$. edentula pada daerah mangrove berlumpur (Lebata, et al., 2001).

\section{PENUTUP}

4.1. Kesimpulan

Berdasarkan hasil dan pembahasan, disimpulkan :

1. Kualitas air di daerah mangrove alami memiliki fluktuasi yang lebar berbeda dengan mangrove rehabilitasi dengan fluktuasi yang sempit.

2. Fraksinasi sedimen pada daerah mangrove alami memiliki fraksi sedimen relatif lebih konstan, sementara pada daerah mangrove rehabilitasi memiliki fraksi sedimen yang fluktuatif.

\subsection{Saran}

Untuk lebih melengkapi data penelitian kualitas air, perlu dilakukan penelitian terintegratif mengenai diversitas dan kerapatan mangrove, struktur komunitas gastropoda dan bivalvia khususnya di Estuari Perancak, Bali sebaiknya dilakukan penelitian mangrove di musim kemarau dan tidak hanya jenis mangrove sejati yang diteliti.

\section{PERSANTUNAN}

Penelitian ini tidak dapat terlaksana dengan baik tanpa bantuan dan pertolongan dari pihak BROK Perancak, Bali. Untuk itu kami mengucapkan terima kasih atas kesediaanya dalam membantu menyediakan peralatan yang dibutuhkan. Selain itu, ucapan terima kasih yang besar kepada saudara Rochmady, S.Pi., M.Si yang telah membantu menyiapkan bahan literatur sehingga analisis data dan pembahasan penelitian ini berjalan dengan baik. 


\section{DAFTAR PUSTAKA}

Bengen, Dietrich G. 2004. Pedoman Teknis Pengenalan dan Pengelolaan Ekosistem Mangrove. Bogor: Pusat Kajian Pesisir dan Pulau-Pulau Kecil (PKSPL), 2004. Vol. 1.

-. 2000. Sinopsis Ekosistem dan Sumberdaya Alam Pesisir. Bogor: Institut Pertanian Bogor, 2000. Vol. 1.

BROK. 2009. Riset Observasi dan Kajian Pemanfaatan Kawasan Konservasi Laut di Estuari Perancak. Bali : Balai Riset dan Observasi Kelautan - DKP, 2009.

Gunarto. 2004. Konservasi Mangrove Sebagai Pendukung Sumber Hayati Perikanan Pantai. Maros: Balai Riset Perikanan Budidaya Air Payau, 2004. Vol. 2.

Hidayatullah, M. dan Pujiono, Eko. 2014. Struktur dan Komposisi Jenis Hutan Mangrove Di Golo Sepang-Kecamatan Boleng Kabupaten Manggarai Barat. Bandung: Jurnal Penelitian Kehutanan Wallacea, 2014. hal. 151-162. Vol. 3.

IUCN. 2007. Environmental and Socio Economic Value of Mangrove in Tsunami Affected; Rapid mangrove Valuation Studi. Sri Lanka : Panama Village in South Eastern Coast, 2007. Vol. 1.

Lebata, Ma Junemie Hazel L. dan Primavera, J.H. 2001. Gill Structure, Anatomy and Habitat of Anodontia edentula; Evidence of Endosymbiosis. New York: Journal of Shellfish Research, 2001. hal. 1273-1278. Vol. 20.

Lebata, Ma Junemie Hazel L. 2000. Element Sulfur in The Gills of The Mangrove Mud Clam Anodontia edentula (Family Lucinidae). Wetland Ecology and Management. January, 2000, Vol. 19, 1, hal. 241-245.

-. 2001. Oxygen, Sulfhide and Nutrient Uptake of The Mangrove Mud Clam Anodontia edentula (Family; Lucinidae). Marine Polution Bulletin. November, 2001, Vol. 42, 11, hal. 1133-1138.

Macintosh dan Ashton. 2002. Review of Mangrove Biodiversity Conservation and Management; The World and Center for Tropical Ecosystems Research (cenTER Aarhus. Denmark : University of Aarhus, 2002. Vol. 1.

MNLH. 2004. Keputusan Menteri Negara Lingkungan Hidup Nomor 51 Tahun 2004 Tentang Baku Mutu Air Laut. Jakarta : Kementerian Negera Lingkungan Hidup, 2004.

Natan, Yuliana. 2008. Studi Ekologi dan Reproduksi Populasi Kerang Lumpur Anodontia edentula Pada Ekosistem Mangrove Teluk Ambon Bagian Dalam. Bogor : Program Studi Ilmu dan Teknologi Kelautan, Institut Pertanian Bogor, 2008. hal. 179. Disertasi.

Noor, Yus Rusila, Khazali, M. dan Suryadiputra, I.N.N. 1999. Pedoman Pengenalan Mangrove di Indonesia. 2. Bogor: Wetlands International Indonesian Programe, 1999. Vol. 1. ISBN 97995899-0-8.

Pratisto, S.A. 2000. Aplikasi SPSS 10.05 Dalam Statistik dan Rancangan Percobaan. Bandung : Alfabeta, 2000.

Pulungsari, A.E. 2004. Komposisi Spesies Gastropoda Di Perairan Hutan Bakau Segara Anakan Cilacap. Bogor: Program Studi Biologi - Sekolah Pascasarjana Institut Pertanian Bogor, 2004. Vol. Tesis.

Riwidikso, H. 2009. Statistik Kesehatan; Belajar Mudah Teknik Analisis Data Dalam Penelitian Kesehatan (Plus Aplikasi SPSS). Yogyakarta : Mitra Cendekia Press, 2009.

Sidik, F. 2005. Coastal Greenbealt. Bali : Balai Riset dan Observasi Kelautan - DKP, 2005.

Susiana. 2011. Diversitas dan Kerapatan Mangrove, Gastropoda dan Bivalvia di Estuari Perancak, Bali. Makassar : Program Pascasarjana, Universitas Hasanuddin, 2011. Vol. Tesis.

Tis'in, Musayyadah. 2008. Tipologi Mangrove Dan Keterkaitannya Dengan Populasi Gastropoda Littorina neritoides (Linne, 1758) Di Kepulauan Tanakeke, Kabupaten Takalar, Sulawesi Selatan. Bogor : Sekolah Pascasarjana - Institut Pertanian Bogor, 2008. Vol. Tesis. 